\title{
APP-087 演題取下げ
}

\section{APP-088 尿中落下細胞からの尿細管上皮前駆様細胞の培養と腎障害治療一腎微小循環からの見地の臨床 と基礎一}

名古屋大学医学部泌尿器科"), 神戸理化学研究所・発生再生科学総合研究センター ${ }^{21}$, 長寿医療センター ${ }^{3)}$

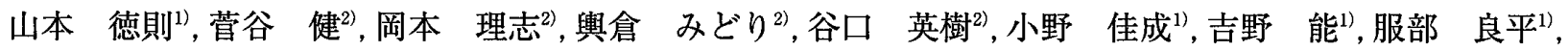
大島 伸一 ${ }^{3)}$, 後藤 百万 ${ }^{1)}$

近年、腎臟再生において細胞治療が容易で臨床応用が最も近いと考えられている尿細管上皮再生が注目されている。そこで我々は、その尿細管上皮再生に おいて関与する骨鹃細胞由来 (特開 2005-13909)、間葉系細胞由来（特願 2006-216234）そして最も大部分を占める腎臟組織由来 (出願 2006-114152) の細 胞を用いた細胞治療についておのおの特許を出願し研究を進めている。なかでも尿細管上皮再生は腎瀻幹/前駆細胞の果たす役割が最も重要と言われてい るが、いまだに尿中落下紐胞からの腎臟幹/前駆細胞の培養やその細胞を用いた治療における報告はない。臨床における腎虚血再灌流例の尿から落下細胞を 採取し、細胞培養を行い尿細管前駆細胞が培養可能か検討し、イヌ虚血再灌流障害モデルでの細胞治潦が可能かどうか検討した。移植腎（生体腎移植 12 症例）血流再開 1 時間を我々が開発した腎拡大内視鏡（特開 2003-171318、特開 2003-329934）を用いて、腎虚血に直接関与する尿細管周囲毛細血管の赤血 球速度と尿管内落下細胞の速度を測定したところ血流再開より 10 分後には評在尿細管内に oscillatory に下流に流れる落下緗胞を確認した。また その細胞 を含んでいる推測される尿中落下細胞採取の時期、血流再開より1時間の尿細管周囲毛細血管血流速度は低下し徐々に、正常速度に回復状態にあることを 明らかにした。またその時の尿を無菌的採取し尿中落下細胞を培養し、78.6\% (11/14)にドーム形成を有する敷石状の增殖能力の高い尿細管由来の細胞 を同定した（コントロールでは培養陰性 (7/7))。また、この細胞は、近位尿細管（アクアポリン $1, \mathrm{Na}+/ \mathrm{Cl}$-共輸送体 (KCC3a)、N-カドヘリン)、遠位 尿細管（カルジオリピン D28K）、胎児の発生期の腎臟に発現する（Pax2,Pax8) 特異的な遺伝子が磼認された。これらの結果から、尿中落下紐胞の初代培 盖中には、発生期の腎䐬に存在する腎臟幹/前駆細胞のような未分化細胞や、近位尿細管>ヘンレイループ〉遠位尿細管と続〈腎ネフロンの尿細管様に分化 された細胞が存在することが示唆された。またこの培養において、幹細胞共通の特徽を有する side population 練胞が $0.33 \%(n=6)$ も存在していた。さ らに、同様な方法で、イヌ腎虚血再灌流モデル $(\mathrm{n}=14)(50$ 分温阻血) の分腎尿からの尿中落下細胞から腎朦幹/前駆細胞の培盖に $100 \%(12 / 12)$ 成功し、 同イヌ単腎症腎虚血再灌流障害モデル $(\mathrm{n}=6)$ に投与し、腎機能と病理組織の改善を認めた。我々は初めて、尿細管周囲毛細血管虚血の回復期の尿中落下

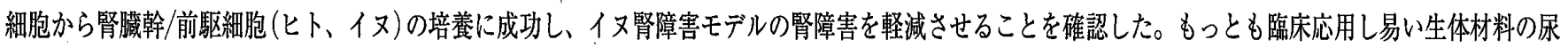
から腎臓幹/前駆細胞培養に成功した医学的意義は高く、今後、虚血性腎不全や急性尿細管壊死の自己細胞治療と非漫襲的で、幅広い臨床応用が期待される。 